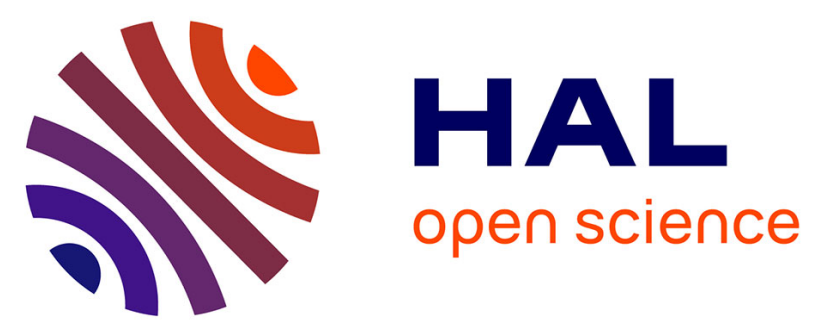

\title{
Organic matter-clay interaction along a seawater column of the Eastern Pacific upwelling system (Antofagasta bay, Chile): Implications for source rock organic matter preservation
}

Adoum Mahamat Ahmat, Mohammed Boussafir, Claude Le Milbeau, Régis Guégan, Jorge Valdès, Marcos Guiñez, Abdelfettah Sifeddine, Lydie Le Forestier

\section{- To cite this version:}

Adoum Mahamat Ahmat, Mohammed Boussafir, Claude Le Milbeau, Régis Guégan, Jorge Valdès, et al.. Organic matter-clay interaction along a seawater column of the Eastern Pacific upwelling system (Antofagasta bay, Chile): Implications for source rock organic matter preservation. Marine Chemistry, 2016, 179, pp.23-33. 10.1016/j.marchem.2016.01.003 . insu-01265816

HAL Id: insu-01265816

https://hal-insu.archives-ouvertes.fr/insu-01265816

Submitted on 1 Feb 2016

HAL is a multi-disciplinary open access archive for the deposit and dissemination of scientific research documents, whether they are published or not. The documents may come from teaching and research institutions in France or abroad, or from public or private research centers.
L'archive ouverte pluridisciplinaire HAL, est destinée au dépôt et à la diffusion de documents scientifiques de niveau recherche, publiés ou non, émanant des établissements d'enseignement et de recherche français ou étrangers, des laboratoires publics ou privés. 


\section{Accepted Manuscript}

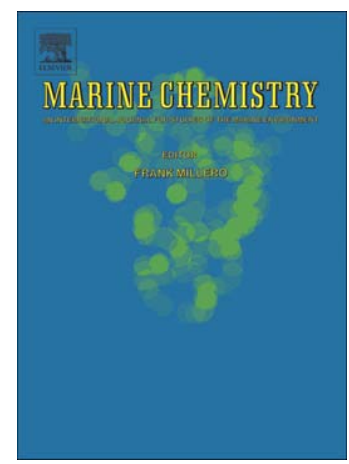

Organic matter-clay interaction along a seawater column of the Eastern Pacific upwelling system (Antofagasta bay, Chile): Implications for source rock organic matter preservation

Adoum Mahamat Ahmat, Mohammed Boussafir, Claude Le Milbeau, Régis Guegan, Jorge Valdès, Marcos Guiñez, Abdelfettah Sifeddine, Lydie Le Forestier

PII: S0304-4203(16)30003-2

DOI: doi: 10.1016/j.marchem.2016.01.003

Reference: MARCHE 3340

To appear in: $\quad$ Marine Chemistry

Received date: 13 July 2015

Revised date: $\quad 2$ December 2015

Accepted date: 20 January 2016

Please cite this article as: Ahmat, Adoum Mahamat, Boussafir, Mohammed, Le Milbeau, Claude, Guegan, Régis, Valdès, Jorge, Guiñez, Marcos, Sifeddine, Abdelfettah, Le Forestier, Lydie, Organic matter-clay interaction along a seawater column of the Eastern Pacific upwelling system (Antofagasta bay, Chile): Implications for source rock organic matter preservation, Marine Chemistry (2016), doi: 10.1016/j.marchem.2016.01.003

This is a PDF file of an unedited manuscript that has been accepted for publication. As a service to our customers we are providing this early version of the manuscript. The manuscript will undergo copyediting, typesetting, and review of the resulting proof before it is published in its final form. Please note that during the production process errors may be discovered which could affect the content, and all legal disclaimers that apply to the journal pertain. 
Organic matter-clay interaction along a seawater column of the Eastern Pacific upwelling system (Antofagasta bay, Chile): implications for source rock organic matter preservation.

Adoum Mahamat Ahmat a,b,c *, Mohammed Boussafir ${ }^{\text {a,b,c }}$, Claude Le Milbeau ${ }^{\text {a,b,c }}$, Régis Guegan ${ }^{\text {a,b,c }}$, , Jorge Valdès ${ }^{\mathrm{d}}$, Marcos Guiñez ${ }^{\mathrm{d}}$, Abdelfettah Sifeddine ${ }^{\mathrm{e}}$, Lydie Le Forestier ${ }^{\mathrm{a}, \mathrm{b}, \mathrm{c}}$

${ }^{a}$ Université d'Orléans, Institut des Sciences de la Terre d'Orléans (ISTO), UMR 7327, 45071 Orléans, France

${ }^{b}$ CNRS/INSU, ISTO, UMR 7327, 45071 Orléans, France

${ }^{c}$ BRGM, ISTO, UMR 7327, BP 36009, 45060 Orléans, France

${ }^{d}$ Laboratorio de Sedimentología y Paleoambientes, Instituto de Investigaciones Oceanológicas, Facultad de Recursos del Mar, Universidad de Antofagasta, Casilla 170, Antofagasta, Chile

${ }^{e}$ LOCEAN, UMR 7159 CNRS-IRD-Univ. P. \& M. Curie-MNHN, 32 Av. Henri Varagnat, 93143 Bondy, France

\section{$\underline{\text { Abstract }}$}

Natural Organic Matter (OM) preservation and sedimentary burial mechanisms are still poorly understood despite their importance in oil source rock characterization and carbon cycle issues. It is now recognized that mineral sorption contributes significantly to $\mathrm{OM}$ preservation by conferring steric protection and preventing enzymatic access. Most of the studies dealing with OM preservation have focused on settled $\mathrm{OM}$, omitting aggregation in the water column. For the first time, we have tested the complexation of natural $\mathrm{OM}$ on 3 types of clays in seawater in-situ conditions. Samples of $\mathrm{Na}$ exchanged montmorillonite ( $\mathrm{Na}$ $\mathrm{MMt}$ ), synthetic montmorillonite (S Na MMt) and natural kaolinite (Kaol) were immersed in an upwelling zone (Antofagasta bay, Chile). Three depths were studied: 15m (photic zone), $40 \mathrm{~m}$ (oxygen transition zone) and $80 \mathrm{~m}$ (anoxic zone). The clayey samples were kept immersed for different durations and analyzed after removal, via GC/MS, Py-GC/MS, flash elementary pyrolysis, DOC analyzer and XRD. The main results are: (1) For the shortest immersion times, DOC analyzes performed on clays' proximal water indicated excessive DOC concentrations compared to seawater values. This attraction effect was however temporary, as values tended to rebalance with seawater concentrations for the longest immersion times. (2) Molecular analyses performed on seawater organic extracts indicated that fatty acids, alkanes, alkyl benzenes and methoxy-benzenes were the main dissolved lipid groups. (3) These lipids were also the main sorbed compounds identified on immersed clays, with a predominance of fatty acids. This is due to the higher availability and better affinity of fatty acids with the clayey samples. (4) Because of its higher specific area and CEC, Na MMt exhibited the best sorption rates compared to Kaol and SNa MMt. X ray analyses performed

\footnotetext{
* Corresponding author. E-mail address: adoum.mahamat-ahmat@etu.univ-orleans.fr (A. Mahamat-Ahmat).
} 
on $\mathrm{Na}$ MMt indicated $\mathrm{d}_{001}$ spacing growths, but these growths are not attributed to $\mathrm{OM}$ intercalation. Sorbed OM is probably located on the external surfaces leaf edges of clays.

Keywords: OM; clays; sorption; preservation; seawater column; GC/MS; x ray

\section{Introduction}

In hydrocarbon resources research, it is widely acknowledged that Organic Matter-Clay Interactions (OMCI) are involved in the successive steps of oil genesis. In fact, the quasi systematic association observed between hydrocarbon resources and fine-grained rocks has triggered numerous studies focusing on the contribution of organo-mineral interactions to sedimentary Organic Matter (OM) preservation (Ransom et al. 1998; Pichevin et al. 2004; Wagai and Mayer 2007; Kögel-Knabner et al. 2008; Mikutta et al. 2009). A positive correlation between specific surface and organic carbon content has been highlighted for continental shelf sediments (Mayer, 1994a,b). The validity of this interdependence relationship is related to the environmental configuration, especially the position of sediments on continental slopes (Milliman, 1994), since the low oxygen concentrations encountered in in the lower slope zones induce an excess of organic carbon / surface area ratios (Mayer, 1994a; Keil and Cowie, 1999). Based on the observation of the relationship between organic content and surface area, physical mechanisms of $\mathrm{OM}$ and mineral particle association have been investigated. A preliminary distribution model of OM suggested a monolayer coating of OM on mineral surfaces (Mayer, 1994a). This monolayer model was subsequently revised (Mayer, 1999) and nowadays, natural OM distribution on mineral surfaces is considered as patchy (Arnarson and Keil, 2001).

From sedimentary genesis to industrial recovery, several studies have highlighted the impact of OMCI in oil-source rock deposition processes. These interactions are observed in sedimentary $\mathrm{OM}$ preservation, kerogen thermal cracking, crude oil migration and hydrocarbon composition change in oil reservoirs (Wu et al., 2012). The catalytic characteristics of clays enhance kerogen cracking (Fan et al., 2004), while diagenetic transformations of clays occurring during the burial process favor crude oil migrations. For example, smectite/illite alteration releases interlayer water molecules (Zhang et al., 2010; Cai et al., 2012), inducing an increase in fluid pressure which drives oil migration. In addition to their interferences in oil migration, clay minerals also interact with crude oil during its accumulation in reservoir rocks. Thus, the adsorption of heavy compounds (resins and asphaltenes) by clay-sized components in reservoirs increases the saturated hydrocarbon 
concentration in free oil, leading to the enhancement of oil rank (Pan et al., 2005). OMCI is also a crucial factor in the crude oil extraction process. The surfactants usually added to chemical slurries in order to reduce capillarity retention by reservoir rocks are frequently lost due to clay adsorption (Liu et al., 2004; Amirianshoja et al., 2013). Surfactant loss minimization methods are currently being developed in the enhanced oil recovery investigation field. Organo-clay processes are involved at each step of the oil genesis and exploitation chain.

The fate of $\mathrm{OM}$ in natural aquatic environments has interested the organic geochemistry communities for several decades. Lakes and up-welling marine areas are sedimentary environments with the most favorable physicochemical conditions for high organic productivity. These environments are propitious for the deposition of hydrocarbon-rich organic sediments if the $\mathrm{OM}$ produced escapes oxidation and bacterial activity. Thus OM preservation at the water/sediment interface has been studied through several approaches (Largeau et al., 1984; Tissot and Welte, 1984; Tegelaar et al., 1989). Most of these studies focused on bulk sediments, establishing three OM preservation pathways. In fact the model based on microscopic observation indicates that the process may be selective (Largeau et al., 1984; Mayer 2004). Alternatively, sedimentary OM preservation could arise from successive steps of degradation and condensation (Tissot and Welte, 1984). It could be favored by a natural sulfurization mechanism, via the incorporation of sulfur atoms in anoxic environments (Tegelaar et al., 1989; Sinninghe Damste and de Leeuw, 1990; Boussafir et al., 1995). Depending on the sedimentary basin configuration and the biotope typology, the effect of these different paths may be combined. Yet, none of these studies considered early intra column organo-mineral flocculation and its possible impacts on the preservation process occurring in underlying sediments.

The 90s saw the rise of a new hypothesis, namely trapping by mineral materials, specifically clays, which is thought to be a full preservation process. OMCI can be divided into three morphological concepts: (i) sorption of small molecules on surfaces via 'classic' mechanisms. These mechanisms are now well characterized: cation bridges, van der Waals effects, ligand exchanges and hydrophobic effects (Arnarson and Keil 2000; Drouin 2007; Keil and Mayer 2014); (ii) sorption of high molecular weight polymers (e.g., proteins); (iii) global flocculation and aggregation phenomena inducing the main physical and steric protection. The importance of organic-mineral interactions in the fossilization of organic matter is well established. Several studies have already suggested that the weight increase 
resulting from organo-mineral complexation is indirectly involved in OM preservation, by helping to reduce the transfer time in water columns (Wakeham 1984; Jackson 1990). Beyond this subsidiary role, evidence highlighting the correlation between organic and mineral sizes in sediments suggests that OMCI interactions could provide effective protection against degradation agents of labile OM (Mayer, 1994a; Keil et al., 1994). Some studies subsequently attempted to further characterize the clay/OM relations in natural sediments, or to model their interaction process in laboratory studies in order to understand their principles and to apprehend their role in the organic carbon cycle.

However, these previous investigations have often based their conclusions on the study of sediments only. Interaction processes that occur in areas of OM production, where OM is likely to be trapped, are poorly investigated. Therefore, the involvement of mineral phases in protecting OM remains today relatively poorly understood. Nowadays it is assumed that sorption of organic molecules reduces their availability to bacterial degradation (Sugai and Henrichs, 1992; Mayer, 1994b; Hedges and Keil, 1995). Rare experimental studies show that in-situ sorption by clays can be considered as a stable mechanism of preservation of hydrocarbon-rich OM (Satterberg et al. 2003; Drouin et al. 2010).

Our work focuses on the initial steps of early diagenesis. The objective is to understand the agglomeration of organo-clays in the water column, in order to better characterize the contribution of OMCIs to the preservation process of kerogen precursor OM. We have chosen to test the role of clays in the adsorption and fossilization mechanism of dissolved OM. For this purpose, the OM sorption of three types of clays was tested in a marine productive upwelling system in three specific physicochemical zones of the water-column. Lipid composition and in situ OM/clay aggregated complexes were investigated via GC/MS and py-GC/MS in order to identify the main molecular groups favored by the sorption process. Sorbed masses were quantified in order to distinguish the most propitious physicochemical zone along the water column and also to identify the most favorable clay type in such a productive upwelling sedimentary environment. The mechanical behavior of expandable clays during the sorption process was also tested along the seawater column.

\section{Materials and methods}

\subsection{Studied site}

Adsorption experiments were performed in Antofagasta bay off the Mejillones peninsula, Chile (figure 1). An arid climate prevails in Antofagasta's hinterland, with rainfalls 
barely superior to $0.5 \mathrm{~mm} / \mathrm{year}$ (Clarke, 2006). The bay undergoes the Humboldt current (Iriarte et al., 2000), which thrusts cold water along the South American coast, from high southern latitudes to north Chilean latitudes. The Humboldt circulation system is locally associated with upwelling currents inducing more than $200 \mathrm{~g} \mathrm{C} / \mathrm{m}^{2} /$ year of biomass (Levin and Rathburn, 2003). A multi parameter probe $\left(\mathrm{YSI}^{\circledR}\right)$ was used to determine seawater column characteristics (temperature, dissolved oxygen, fluorescence, salinity).

\subsection{Clays and immersion traps}

Three clay samples were selected for this study: two smectites (natural and synthetic, respectively) and one natural kaolinite. The natural smectite is the SWy-2 Wyoming montmorillonite supplied by the Source Clay Minerals Repository of the Clay Minerals Society. This SWy-2 montmorillonite was sodium-saturated by exchange in $1 \mathrm{M} \mathrm{NaCl}$, as described in Le Forestier et al. (2010). After dialysis and decantation, the $<2 \mu \mathrm{m}$ fraction of Na-SWy2 samples was recovered, dried and finely hand ground in an agate mortar. This sample is hereafter named $\mathrm{Na} \mathrm{MMt}$. The synthetic smectite, S Na MMt, was synthesized at hydrothermal conditions $\left(350^{\circ} \mathrm{C}, 120 \mathrm{MPa}\right)$ during 28 days in an autoclave system (Tuttletype, externally heated, cold-seal pressure vessels) from a gel of anhydrous composition $\left(0.33 \mathrm{Na}_{2} \mathrm{O}-1.67 \mathrm{Al}_{2} \mathrm{O}_{3}-0.66 \mathrm{MgO}-8 \mathrm{SiO}_{2}\right)$, using the procedure of Le Forestier et al. (2010). The natural $\mathrm{Na}$ MMt smectite still contained impurities (quartz, pyroxene) after purification, whereas the synthetic S Na MMT was characterized by a higher purity with one crystalline phase. Kaolinites were sampled at Ploemeur kaolin stone-pit (Morbihan, France) which is a deposit deriving from hydrothermal and climatic alteration of Hercynian leucogranites.

In terms of specific surface and cationic exchange capacity, natural kaolinite presents significant differences with the smectites (table1). Adsorption efficiency according to clay mineralogy was therefore tested by considering the results obtained on this second type of clay. The clayey samples were immersed in the water column at different depths $(15 \mathrm{~m}$, 40m, 80m) using cylindrical systems of traps (Drouin, 2007). The traps dimensions were $4 \mathrm{~cm}$ in diameter and $4.5 \mathrm{~cm}$ in height. Their edges were equipped with porous hydrophilic membranes $(0.45 \mu \mathrm{m}) .150 \mathrm{mg}$ of each clayey type bathing in $50 \mathrm{ml}$ of ultrapure water (Milliq, Millipore ${ }^{\circledR}$ ) were inserted in the traps.

\subsection{Dissolved Organic Carbon measurement}


Dissolved Organic Carbon (DOC) concentrations were determined in triplicate using a Shimadzu@ TOC 5000A total organic carbon analyzer. These analyses were conducted on natural seawater at various depths, on blank water traps devoid of clays and water traps in which interaction with clays occurred.

\subsection{Lipid analyses}

\subsubsection{Seawater lipids}

Three water samples were collected at the respective depths of $25 \mathrm{~m}, 40 \mathrm{~m}$ and $80 \mathrm{~m}$ corresponding to different physico-chemical zones (oxygenic, transition and anoxic) of the water column. Lipids were extracted with diethyl ether and separated into neutral and acidic fractions using aminopropyl bonded silica as the liquid chromatography stationary phase. Neutral fractions were silylated by using BSTFA in pyridine at $60^{\circ} \mathrm{C}$. The acid fraction was methylated by adding a mixture of anhydrous $\mathrm{MeOH}$ and acetyl chloride. $5 \alpha(\mathrm{H})$-cholestane, was used as internal standard prior to analysis.

Analyses were performed on a Trace GC Ultra gas chromatograph (GC) coupled to a TSQ Quantum XLS mass spectrometer equipped with an AS 3000 autosampler (both from Thermo Scientific). The GC was fitted with a Thermo Trace Gold TG-5 MS capillary column (60 m, $0.25 \mathrm{~mm}$ i.d., $0.25 \mu \mathrm{m}$ film thickness). The temperature of the column was held at $40^{\circ} \mathrm{C}$ for $1 \mathrm{~min}$, and then increased from 40 to $120^{\circ} \mathrm{C}$ at $30^{\circ} \mathrm{C} \cdot \mathrm{min}^{-1}$, and then from 120 to $300^{\circ} \mathrm{C}$ at $3^{\circ} \mathrm{C}$. $\mathrm{min}^{-1}$ with a final isothermal hold at $300^{\circ} \mathrm{C}$ for $30 \mathrm{~min} .2 \mu \mathrm{L}$ of sample was injected in splitless mode at $280^{\circ} \mathrm{C}$. Helium was the carrier gas $(1 \mathrm{ml} / \mathrm{min})$. The mass spectrometer was operated in EI mode at $70 \mathrm{eV}$, from $\mathrm{m} / \mathrm{z} 50$ to 600.

\subsubsection{Sorbed lipids}

Lipids adsorbed onto clay samples were analyzed using a CDS Pyroprobe 5150. $10 \mathrm{mg}$ of sample were introduced in quartz tubes $(1.5 \mathrm{~mm} \quad \mathrm{x} 2 \mathrm{~cm}) .10 \mu \mathrm{L}$ of TetraMethylAmmonium Hydroxide (TMAH) and $2 \mu \mathrm{L}$ of internal standard ( $5 \alpha$-cholestane, $\mathrm{C}$ $=96 \mathrm{mg} / \mathrm{L}$ ) were added to each tube and the tubes were kept at room temperature during $12 \mathrm{~h}$.

The pyrolysis was carried out at $650^{\circ} \mathrm{C}$ for $30 \mathrm{~s}$, at a heating rate of $20^{\circ} \mathrm{C} / \mathrm{ms}$. Pyrolysates were sent to the GC injector through a transfer line maintained at $300{ }^{\circ} \mathrm{C}$. The pyGC/MS coupling comprises a GC-TRACE® (THERMOQUEST®) chromatograph and a GCQ POLARIS ${ }^{\circledR}\left(\right.$ FINNIGAN ${ }^{\circledR}$ ) mass spectrometer. The separation process took place on a RESTEK RTX-5Sil MS capillary column (30m in length, $0.25 \mathrm{~mm}$ internal diameter, $0.25 \mu \mathrm{m}$ 
film thickness and 5m security length). The GC / MS analytical conditions were similar to those used for the seawater lipids.

\subsubsection{Expandable clays interleaf spacing}

Clayey samples $\mathrm{d}_{001}$ spacing before and after immersion were determined by the first $00 l$ reflection from the X-ray patterns which were recorded in a conventional $\theta-\theta$ Bragg-Brentano configuration by using a Thermo Electron ARL'XTRA diffractometer equipped with a $\mathrm{Cu}$ anode $(\mathrm{CuK} \alpha 1,2=1.5418 \AA)$ coupled with a $\mathrm{Si}(\mathrm{Li})$ solid detector. Dried sample $\left(100^{\circ} \mathrm{C}\right.$ for 24 hours) diffractograms were performed between 2 and $64^{\circ}(2 \theta)$ with angular and time steps of $0.04^{\circ}$ and 10 s respectively.

\section{Results}

\subsection{Marine water column characteristics}

\subsubsection{Physico-chemical properties}

The oxygen profile presented a maximum high peak at $12 \mathrm{~m}$ of depth (Fig. 2). Deeper $\mathrm{O}_{2}$ concentration decreased progressively and reached total anoxia at $70 \mathrm{~m}$. Based on this oxycline, three main zones were distinguished: oxygenic, transitional and anoxic. The oxygenic zone covers the first 30 meters and includes the maximum peak of fluorescence. This zone is assimilated to the productive photic zone. The transitional zone extends from 30 to $52 \mathrm{~m}$. Anoxia prevails beyond. A slight renewal of oxygenation was observed at $60 \mathrm{~m}$. The circulation of deep marine currents probably generated this rise in dissolved oxygen. A thermocline marks the beginning of a continuous drop in temperature towards $8 \mathrm{~m}$ of depth, which also coincides with a drastic drop in salinity (Fig. 2).

\subsubsection{Dissolved Organic Carbon (DOC)}

\section{Seawater DOC profile}

The highest DOC values were observed in the photic zone (Fig. 3). With growing depth, DOC decreased continuously similarly to the oxygen trend (Fig. 2). The slight DOC renewal at $60 \mathrm{~m}$ coincided with a slight oxygen increase, highlighting the synchronous evolution of the two parameters. Oxygen is in fact a DOC control factor since OM oxidative degradation increases DOC levels of water. This is particularly the case in the lowest depths where extensive atmospheric/oceanic exchanges involve higher oxidative degradation rates and 
consequently higher DOC inputs. The DOC profile does not correlate with fluorescence (Fig. 2). Thus DOC is more associated with oxygenation than primary production.

\section{Clay traps DOC}

The DOC values measured in water samples extracted from Na MMt traps immersed during two days were higher than seawater DOC concentration (fig.3). Low organic concentrations measured in blank traps (table 2) highlighted clays effect on organic influx within the traps. The attraction effect decreased considerably after a week. This trend was observed in the three physicochemical zones. Similar behavior was observed in water samples extracted from the S Na MMt traps (Fig.3). Thus, clay samples influence DOC concentrations in the surrounding water.

\subsubsection{Seawater lipid composition}

The acidic fraction chromatogram (Fig. 4A) was dominated by Fatty Acids (FA). Short carbon lengths $\left(\mathrm{C}_{14}\right)$ as well as relatively long carbon lengths $\left(\mathrm{C}_{24}\right)$ were observed. FA global distribution showed a classical predominance of palmitic acid $\left(\mathrm{C}_{16}\right)$ and steraic acid $\left(\mathrm{C}_{18}\right)$. Espinosa et al. (2009) described a similar distribution in Antofagasta Bay. It is a typical distribution of phytoplankton-derived FA. Saturated ones were the most abundant and were punctually preceded by their unsaturated homologues. Monounsaturated hexadecanoic acid $\left(\mathrm{C}_{16: 1}\right)$ was the most recurrent unsaturated homologue. The global proportion declined with growing depth, with higher amounts in the photic zone than in the transitional and anoxic zones.

The neutral fraction principally contained alkanes, and to a lesser extent, alkyl benzenes (Fig. 4B). Indeed, total ionic current showed a high proportion of saturated alkanes preceded by their unsaturated homologues. Long alkane lengths $\left(\mathrm{C}_{32}\right)$ as well as relatively short lengths $\left(\mathrm{C}_{24}\right)$ were identified. Alkyl benzenes were observed for low retention times with relatively low intensities. The photic zone was richer than the transitional and anoxic zones. Similarly to FA evolution, the neutral fraction amount decreased with growing depth.

\subsection{Sorbed lipid groups and relative amounts}

\section{On natural Wyoming montmorillonite (Na MMt)}

Py/GC-MS analyses performed on immersed samples revealed the adsorption of FA, alkanes, and alkyl benzenes (Fig.5). Although long carbon chains were observed in water extracts, the linear molecules adsorbed onto $\mathrm{Na}$ MMt were relatively short. FA were the most 
adsorbed molecular group whether in the photic, transitional or anoxic zones. FA adsorption was relatively more efficient in the photic zone than in the transitional and anoxic ones. Lignoceric acid $\left(\mathrm{C}_{24}\right)$ was the longest remarkable adsorbed molecule (Fig.6). Palmitic acid $\left(\mathrm{C}_{16}\right)$ and steraic acid $\left(\mathrm{C}_{18}\right)$ were otherwise the most represented compounds (Fig.6). This is predictable given that these molecules are the most abundant in water samples (Fig. 4A). For a short duration of immersion, cyclic molecules such as alkyl benzenes were also identified. Some other aromatic compounds, such as phenols, methoxyl benzenes and polycyclic alkanes, were also adsorbed. The adsorption of alkanes was highly efficient in the photic zone. In fact, the photic zone is the most propitious water column zone for the adsorption of linear molecules.

As in the case of the natural analogue $\mathrm{Na} \mathrm{MMt,} \mathrm{the} \mathrm{py-GC/MS} \mathrm{results} \mathrm{of} \mathrm{S} \mathrm{Na} \mathrm{MMt}$ were dominated by FA, with a maximal adsorption in the photic zone (Fig. 5). Alkanes, alkyl benzenes and other aromatic compounds (methoxy benzenes and phenols) were also present. Total FA masses were however lower than on the natural analogue (table 2).

The lipids adsorbed on kaolinite were mostly FA (Fig.6). Alkanes and alkylbenzenes were also adsorbed but in lower intensities. The molecular diversity of this clay was greater than for montmorillonites.

\section{3-3 Expandable clays interleaf spacing behavior}

$\mathrm{X}$-ray analyses performed on immersed and non-immersed montmorillonite samples showed $d_{001}$ spacing growths (Fig. 9). $d_{001}$ spacing increased from $9.8 \AA$ in the Na MMt nonimmersed sample to an average value of $13.9 \AA$ in immersed samples. The same increasing trends were observed for S Na MMt: $\mathrm{d}_{001}$ spacing rose from $10 \AA$ to $11.8 \AA$ on average. On both montmorillonites, growth was slightly more favored in the transitional and anoxic zones compared to the photic one. These interleaf spacing fluctuations suggest the intercalation of dissolved compounds. It was not possible, however, to assess the nature of these intercalated compounds. They could be organic as well as inorganic.

3-4 Sorbed amounts compared to the monolayer equivalent zone

Sorbed amounts versus clay specific surfaces are plotted in Fig 8. A Monolayer Equivalent (ME) zone was delimited as in Hedges and Keil (1995). Kaol, Na MMt and S Na MMt sorbed carbon amounts are clearly under the ME zone. They are comparable with the amounts found in Equatorial Pacific sediments (Hedges and Keil 1995). 


\section{Discussion}

DOC analysis results indicated that clays induce fluctuations in organic concentrations in the near aqueous environment of the interaction traps, since carbon concentrations in trap water exceeded blank traps and external seawater concentrations (Fig.3). This trend was observed for both montmorillonites and kaolinite. Excess DOC suggests an electrostatic influence of clay ionic elements on oppositely charged organic compounds. Indeed the Chilean littoral is known for its dissolved metals content (Böning et al., 2005; Valdes et al. 2008; Valdes et al. 2014, Ortiz et al. 2015). These elements (e.g. $\mathrm{Fe}^{2+}$, in the anoxic zone), are not only involved in sedimentary OM preservation via co-precipitation of an organometallic complex (Eglinton 2012; Lalondes et al., 2012), they are also incorporable in clay networks via cationic exchange mechanisms promoting organic sorption (Cervini-Silva et al., 2000; Saidy et al., 2013). The assimilation processes of metal elements probably increased the electric potential of our immersed clay samples, leading to the attraction of negatively charged organic compounds (e.g. fatty acids). In fact seawater basic $\mathrm{pH}$ (about 8) favors the negative charges of the carboxylic extremities of fatty acids and other organic compounds containing the same functional group. These include the acidic function of amino acids and many GC/MS untreated compounds. Our results suggest that the OM-clay association is weak and temporary. Undeniably the organic carbon concentrations enriched the maximum for two days of clay immersion, and tended to rebalance with seawater values for a longer interaction time (Fig 3). This trend fits with the behavior of sorbed compounds (Fig 7). Sorbed amounts decreased between two and seven days, suggesting that desorption occurred during this interlude. The transient behavior probably resulted from the nature of chemical bonding, which associated the organic compounds to clay surfaces. Most of bonding mechanisms (e.g. hydrogen bonding, van der Waals and hydrophobic effects) occur with low energies, involving de facto unstable and temporary organo-clay associations.

$\mathrm{OM}$ preservation arising from these flocculation processes is efficient with the condition of a rapid aggregates transfer through low depths. However, rapid decantation also occurs in relatively deep systems like Antofagasta bay, if aggregate's sizes are high enough. Indeed, if a $1 \mathrm{~mm}$ aggregate takes $\sim 1300$ days before joining the sedimentary interface and a 2 mm flocculate settles after 120 days, empirical Stoke law attests, for pure clay particles, that a $16 \mathrm{~mm}$ aggregate integrates the sediments after 5 days of suspension in a theoretical 
configuration without marine currents. Thus the protective sorption will be efficient if settling aggregates are larger enough to allow minimal transfer time.

Clay-sorbed compounds (Fig 5), i.e. alkanes, alkyl-benzenes, methoxy-benzenes and fatty acids, reflect seawater lipid composition (Fig 4). Fatty acids were the most represented group (table3). Thus, the high sorptions of these molecules with clay-sized minerals, already proven in a soil context (Jagadamma et al., 2014) and a lacustrine environment (Drouin, 2007), is also valid in a seawater environment. This is due to both molecular availability in the water column (Espinosa et al., 2009) and high polarity. The carboxylic functions of fatty acids promote chemical bonding such as cation-bridges or cationic-exchanges, leading to stronger connections with clay sorption sites. As previously discussed, seawater cationic content exchanges with clay ions during compensation processes and consequently increases the clays' sorption capacity. For the same reason, the low sorption of non-polar molecules such as alkanes, alkyl benzenes and methoxy-benzenes results from their low availability in seawater and their low affinity with clay minerals. Contrary to the high-energy bonds possible between fatty acids and clay phases, they establish unstable van der Waals and hydrogen bonds.

Our results also show that the lipid-clay complexation efficiency is heterogeneous along the oceanic column. Despite higher organic availability in the photic zone (Fig 3), the sorption process is more efficient in the anoxic zone compared to the rest of the seawater column (Fig 7 and table 4). High sorptions in this zone were promoted by the variations of water physico-chemical characterictis. As reported in natural $\mathrm{OM} /$ clays sorption experiments (Means 1995; Aarnarson and Keil 2000; Turner and Rawling 2001, Site 2001), and standard batch laboratory experiments (Meyers and Quinn 1973; Thiebault et al 2015; Berhane et al., 2015) acidic conditions, low temperature and high salinity are favorable parameters for OM sorption. Although in our studied site, the marine column $\mathrm{pH}$ was globally basic, measures showed a progressive $\mathrm{pH}$ decrease with growing depth (supplementary data).Water column temperature turned from $20^{\circ} \mathrm{C}$ to $12^{\circ} \mathrm{C}$ in the deepest zone (Fig 2) and salinity was slightly more elevated in the anoxic zone compared to the other depths of experimentations (Fig 2). So the high sorption in the anoxic zone efficiency was not triggered by the lack oxygen itself, it probably resulted from the conjunction of environmental factors (salinity, $\mathrm{pH}$, temperature) particularly

Results also demonstrate that the sorption behavior of the three clays studied differs. Their respective sorption efficiency is as follows: $\mathrm{Na} M M t>K a o l>S \mathrm{Na} M M t$. 
Hydrothermal synthesis conditions explain the lack of favorability of S Na MMt. Le Forestier et al. (2010) showed that the autoclave condition confers a higher crystallinity and better network layout to synthetic smectite, thereby reducing its reactivity. This confirms that the chemical disorder, surface roughness and impurities of natural clays play a favorable role in OMCI mechanisms in sedimentary environments.

Although the sorption rate is clearly higher on natural montmorillonite compared to the synthetic one, $\mathrm{X}$-ray results show that $\mathrm{d}_{001}$ spacing growths are quasi similar on the two clays (Fig 9), suggesting that interlayer growths are induced by the intercalation of non-lipid substances. Immersed montmorillonite samples probably intercalated inorganic cations via exchange mechanisms. So, despite the importance of expandable clays in OM preservation processes highlighted in recent studies (Kennedy al., 2002; Kennedy and Wagner 2011; Arndt and Jorgensen, 2013), our results suggest that interlayer growths do not explain their high sorption efficiency, thus implying the involvement of further physico-chemical characteristics. Thus we suggest that lateral and external surfaces are the main areas involved during the sorption process. Yet it cannot be excluded that OM encapsulation in nano and micro pores between clay particles may also take place and that this mechanism may induce preservation (Kaiser and Guggenberger 2007; Curry et al., 2007; Mayer et al., 2004) by preventing enzymatic access and multiplying molecular sorption sites.

The difference in efficiency observed between $\mathrm{Na}$ MMt and Kaol is also the consequence of heterogeneities in their physical and crystallo-chemical characteristics. In fact Na MMt, a 2:1 type clay, is radically different from Kaol, a 1:1 type clay, in terms of Cation Exchange Capacity (CEC), specific area (table 1) and interlayer content. Greater specific area and CEC are probably the causes of the better reactivity of $\mathrm{Na}$ MMt. The higher predisposition of aromatic compounds to interact with Na MMt compared to Kaol highlighted in batch experiments (Feng et al., 2005) is an additional factor explaining the better sorption rates of Na MMt. The results obtained by Drouin (2007) on OMCI in lake environments, comparing low- and high-charge smectites, showed that low-charge clays are favorable to the sorption of benzenic and poly-aromatic compounds.

For the most propitious immersion time ( 2 days), sorbed amounts ranged between 0.25 and $1.1 \%$ (Fig 8). The highest values were observed in the anoxic zone: respectively $1.01 \%$, $0.88 \% 0.11 \%$ on S Na MMt, Na MMt and Kaol. This shows that clay sorption in one of the most productive areas of the East Pacific up-welling system, does not fit with the Monolayer Equivalent (ME) theory $(y=0.99 x-1.7)$ as delimited in Mayer (1994a) and reintroduced in 
Hedges and Keil (1995). The ME concept, defined for sedimentary OM, assumes a continuous coating on mineral surfaces. In our approach, sorbed amounts are relatively low and consequently excluded from the $\mathrm{ME}$ zone. This confirms that $\mathrm{OM}$ is distributed discontinuously on clay surfaces, suggesting a punctual distribution of OM, located on discrete adsorption sites. The surface distribution of $\mathrm{OM}$ on these seawater complexes is probably patchy as suggested for settled OM in previous studies (Ransom et al., 1997; Arnarson and Keil 2001)

These results also show that the transfer and preservation of HC-rich organic material to the sediments cannot be explained by molecular sorption alone. Other association mechanisms are possible between clays, inherited resistant organic particles and /or complex Bio-geo-polymers. Clays play in this case a steric and physical protection role, preventing access to bacteria enzymes. Previous investigations on the ME concept were performed mainly from the analysis of sediment samples, in particular surface sediments (Keil et al. 1994; Hedges and Keil 1995). We have now ascertained that the ME carbon analyzed here, in addition to isolated adsorbed molecules of DOC of the water-column, contains some polymers and organic particles associated to the clays of the sediment samples that are usually studied. Low sorbed amounts suggested that further mechanisms such as sulfuration in anoxic environments, and/or selective preservation of bioresistant organic compounds (Largeau et al. 1986; Boussafir et al., 1995; Boussafir and Lallier-Vergès, 1997; Salmon et al., 2000; Riboulleau et al., 2001) should be considered in addition to the water column aggregation to explain the preservation of settled OM.

\section{Conclusion}

Several studies have demonstrated the importance of organic sorption on mineral phases, particularly the clay faction, in the preservation process of sedimentary OM and have highlighted the significant role it plays in organic carbon burial. The characterization of these processes is essential to understand the thermo-barometric fate of $\mathrm{H}-\mathrm{C}$ resource precursors. For the first time, we have performed organic sorption on clayey phases in a productive seawater column.

Three main conclusions can be drawn from this study: (i) Clay minerals do not only sorb surrounding OM, they also cause DOC overconcentration in proximal water. Compared to the seawater DOC, an excessive concentration was measured in the clay traps. This attraction is however temporary as concentrations tend to rebalance with seawater values after 
7 days. (ii) Among the sorbed compounds, the FA group is the most was the most represented one. This is related to the high availability and affinity of FA with clayey minerals. (iii) Data indicated that sorption efficiency depends on clay typology and immersion depths. Thus natural Wyoming montmorillonite (Na saturated) is the most favorable clay for dissolved lipids sorption and the anoxic zone of the water column appears to be the most propitious zone. Differences in physical characteristics, notably specific area and CEC, explain natural montmorillonite's better affinity with dissolved lipids. $X$ ray analyses indicated that the $\mathrm{d}_{001}$ spacing of montmorillonites increased during immersion, contrary to that of kaolinite. These growths are however not attributed to lipid intercalation.

Temporal approaches lead to the conclusion that the transfer time of settling particles must be minimal for optimal interactions with seawater lipid content, since beyond 2 days the sorption process is less efficient. Hence, seawater lipid/clay flocculation is not only a function of lipid availability, clay typology and oxygen conditions, it is also conditioned by the intrinsic characteristics of flocculates (size, agglomerates weight). These characteristics must allow a transfer time at least less than 2 days.

Besides, results also highlighted that these water column aggregation processes affected a relatively low part of settling OM. Indeed sorbed organic compounds represented $1 \%$ of the organo-clays complexes in the most favorable cases, whereas organic loads of the sedimentary interface reach almost 5\% (Niggemann et al., 2007). This gap involves the existence and the influence of supplementary preservation mechanisms which allow such organic concentrations within the sediments. We believe that a single mechanism as usually presented in the literature cannot explain the preservation of sedimentary OM. Further preservation mechanisms (vulcanization, inherited bio-resistance etc.) have to be considered. Natural OM preservation probably derives from the addition of protective mechanisms which relative preponderances depends on water columns' chemistry, organic molecules' typology and basins' sedimentation rates.

\section{$\underline{\text { Acknowledgements }}$}

This study was supported by the CESSUR project funded by the INSU/CNRS. A.Mahamat Ahmat benefits from a Ph.D. grant provided by the Région Centre, France. We thank the Labex Voltaire for the financial support and the anonymous reviewer for his constructive remarks. Our gratitude goes also to Thomas Thiebault and Elisabeth RowleyJolivet for their linguistic contribution. 


\section{Figure captions:}

Figure 1 : Study site location (2331'4.6'’South 70²9'30'’West).

Figure 2 : Study site water column physico-chemical characteristics. Clay traps were immersed in the photic, transitional and anoxic zones.

Figure 3: Dissolved Organic Carbon (DOC) concentrations measured in clay traps (horizontal bars) immersed in the photic zone $(20 \mathrm{~m})$, transitional zone $(40 \mathrm{~m})$ and anoxic zone $(80 \mathrm{~m})$. The continuous line represents DOC concentrations measured in seawater.

Figure 4 : Total ionic current (TIC) obtained for water sample extracts in the photic zone (the same results were observed in the transitional and anoxic zones). The upper TIC represents acidic fraction results, the lower one represents neutral fraction results.

Figure 5 : Main lipidic groups adsorbed on immersed clay samples.

Figure 6 : Fatty acid amounts on immersed clay samples.

Figure 7: Total lipid amounts adsorbed on immersed clay samples. (Ph: Photic zone; Tr: Transition zone; An: Anoxic zone).

Figure 8: External pecific areas of clays versus sorbed organic amounts on kaolinite (a) Natural montmorillonite (b) and synthetic montmorillonite (c) samples. Circles, squares and diamonds represent respectively the photic, transitional and anoxic zones. Black sea(x) and Equatorial Pacific (+) sediments are also represented (Data from Hedges and Keil 1995).

Figure 9 : Immersed montmorillonites $d_{001}$ spacing compared with non-immersed samples. (PH: photic zone; TR: transitional zone; AN: Anoxic zone).

\section{Table captions:}

Table 1: Clays' physical characteristics (CEC: Cationic Exchange Capacity).

Table 2: Dissolved Organic Carbon concentrations measured in traps without clay samples (with mean error margins obtained for triplicated measures). The empty cylinders were immersed in the photic zone $(20 \mathrm{~m})$ transition zone $(40 \mathrm{~m})$ and anoxic zone during 2 days.

Table 3: Sorbed lipids amounts normalized by adjacent DOC concentrations (PH: photic zone; TR: transitional zone; AN anoxic zone). 
Table 2: Dissolved Organic Carbon concentrations measured in traps without clay samples (with mean error margins obtained for triplicated measures). The empty cylinders were immersed in the photic zone $(20 \mathrm{~m})$ transition zone $(40 \mathrm{~m})$ and anoxic zone during 2 days.

\section{References}

Amirianshoja T., Junin R., Idris A. K., Rahmani O., 2013. A comparative study of surfactant adsorption by clay minerals. Journal of Petroleum Science and Engineering.101, 21-27.

Arnarson T. S., Keil R.G., 2000. Mechanisms of pore water organic matter adsorption to montmorillonite. Marine Chemistry 71, 309-320.

Arnarson T. S., Keil R.G., 2001.Organic-mineral interactions in marine sediments studied using density fractionation and X-ray photoelectron spectroscopy. Organic Geochemistry 32, 1401-1415.

Arndt S., Jorgensen B.B., 2013. Quantifying the degradation of organic matter in marine sediments: A review and synthesis. Earth-Science Reviews 123, 53-86.

Berhane T.M., Levy J., Krekeler M.PS., Danielson N.D., Stalcup. A., 2015. Sorptiondesorption of carbamazepine bypalygorskite-montmorillonite (PM) filter medium. Journal of Hazardous Materials. 282, 183-193.

Boussafir M., Gelin F., Lallier-Vergès E., Derenne S., Bertrand P., Largeau C., 1995. Electron microscopy and pyrolysis of kerogen from the Kimmeridgien Clay Formation, UK: Source organisms, preservation processes, and origin of the microcycles. Geochimica et Cosmochimica Acta 59, 3731-3747.

Boussafir M and Lallier-Vergès E., 1997. Accumulation of organic matter in the Kimmeridge Clay formation $(\mathrm{KCF})$ : an update fossilisation model for marine petroleum sourcerocks. Marine and Petroleum Geology 14 (1), 75-83.

Böning P., Cuypers, S., Grunwald, M., Schnetger, B., Brumsack, H., 2005. Geochemical characteristics of Chilean upwelling sediments at $\sim 36^{\circ} \mathrm{S}$. Marine Geology 220, 1-21.

Cai J.G., Lu L.F., Bao Y.J., Fan F., Xu J.L., 2012. The significance and variation characteristics of interlay water in smectite of hydrocarbon source rocks. Science in China,Series D: Earth Sciences 55, 397-404.

Cervini-Silva J., Wu J., Stucki J.W., Larson R.A., 2000. Adsorption kinetics of pentachloroethane by iron-bearing smectites. Clays and clay minerals 48, 132-138.

Clarke J.D.A., 2006. Antiquity of aridity in the Chilean Atacama Desert. Geomorphology 73, 101-114. 
Curry K.J., Bennett R.H., Mayer L.M., Curry A., Abril M., Biesiot P.M., Hulbert H.M., 2007. Direct visualization of clay microfabric signatures driving organic matter preservation in fine-grained sediment. Geochimica et Cosmochimica Acta 71(7), 17091720.

Drouin S., 2007. Rôle des argiles dans la préservation et la fossilisation de la Matière Organique pétroligène. Thèse de l'Université d'Orléans, 216p.

Drouin S., Boussafir M., Robert J.L., Albéric P., Durand A., 2010. In vitro experiments of carboxylic acids sorption on synthetic clays in natural marine water. Implication on organic clayey rich sedimentation. Organic Geochemistry 41, 192-199.

Eglinton T I., 2012. A rusty carbon sink. Nature 483, 165-166.

Espinosa L.F., Pantoja S., Pinto L.A., Jürgen R., 2009. Water column distribution of phospholipid-derived fatty acids of marine microorganisms in the Humboldt Current system off northern Chile. Deep-Sea Res II 56 1063-1072.

Fan H., Zhang Y., Lin Y., 2004. The catalytic effects of minerals on aquathermolysis of heavy oils. Fuel 83, 2035-2039.

Feng X., Simpson A.J., Simpson M.J., 2005. Chemical and mineralogical controls on humic acid sorption to clay mineral surfaces. Organic Geochemistry 36, 1553-1566.

Hedges J. I. and Keil R. G., 1995. Sedimentary organic matter preservation: an assessment and speculative synthesis. Marine Chemistry 49, 81-115.

Iriarte J.L., Pizarro G., Troncoso V.A., Sobarzo M. 2000. Primary production and biomass of size-fractionated phytoplankton off Antofagasta, Chile _23-248S/ during pre-El Niño and El Niño1997. Journal of Marine Systems 26, 37-51.

Jackson G.A., 1990. A model of the formation of marine algal flocs by physical coagulation processes. Deep Sea Research Part A. Oceanographic Research Papers 37, 1197-1211.

Jagadamma S., Mayes M.A., Zinn Y.L., Gisladottir G., Russel A.E., 2014. Sorption of organic carbon compounds to the fine fraction of surface and subsurface soils. Geoderma 213, 79-86.

Kaiser K., Guggenberger G., 2007. Sorptive stabilization of organic matter by microporous goethite: Sorption into small pores vs. surface complexation. European Journal of Soil Science 58(1), 45-59.

Keil R.G., Hu F.S., Tsamakis E.C., Hedges J.I., 1994. Pollen in marine sediments as an indicator of oxidation of organic matter. Nature 369, 639-641. 
Keil R.G and Cowie G.L., 1999. Organic matter preservation through the oxygen-deficient zone of the NE Arabian Sea as discerned by organic carbon: mineral surface area ratios. Marine Geology 161, 3-22.

Keil R.G and Mayer L.M., 2014. Mineral matrices and organic matter. Treatise on Geochemistry (Second Edition) 12, 337-359.

Kennedy M.J., Pevear D.R., Hill R.J., 2002. Mineral surface control of organic carbon in black shale. Science 295, 657-660.

Kennedy M.J. and Wagner T (2011). Clay mineral continental amplifier for marine carbon sequestration in a greenhouse ocean. Proceedings of the National Academy of Sciences of the United States of America 108, 9776-9781.

Kögel-Knabner I., Guggenberger G., Kleber M., 2008. Organo-mineral associations in temperate soils: Integrating biology, mineralogy, and organic matter chemistry. Journal of Plant Nutrition and Soil Science-Zeitschrift Fur Pflanzenernahrung Und Bodenkunde 171(1), 61-82.

Lalonde, K., Mucci, A., Ouellet, A., Gélinas, Y., 2012. Preservation of organic matter in sediments promoted by iron. Nature 483, 198-200.

Largeau C., Casadevall E., Kadouri A., Metzger P., 1984. Formation of botryococcus-derived kerogens. Comparative study of immature torbanites and of the extant alga Botryococcus braunii. Organic Geochemistry 6, 327-332.

Largeau C., Derenne S., Casadevall E., Kadouri A., Sellire N., 1986. Pyrolysis of immature Torbanite and the resistant biopolymer (PRB A) isolated from extant alga Botryococcus braunii. Mechanism of the formation and structure of torbanite. In: D. Leythäuser and J. Rullkötter eds, Advances in Organic Geochemistry 1985, Pergamon Press, Oxford, Organic Geochemistry 10, 1023-1032.

Le Forestier L., Muller F., Villiéras F., Pelletier M., 2010. Textural and hydration properties of a synthetic montmorillonite compared with a natural Na-exchanged clay analogue. Applied Clay Science. 48, 18-25.

Levin L.A. and Rathburn A., 2003. Bioturbation by symbiont-bearing annelids in near-anoxic sediments: Implications for biofacies models and paleo-oxygen assessments. Palaeogeography, Palaeoclimatology, Palaeoecology 199, 120-140.

Liu Q., Dong M., Zhou W., Ayub M., Zhang Y.P., Huang S., 2004. Improved oil recovery by adsorption-desorption in chemical flooding. Journal of Petroleum Science and Engineering 43, 75-86. 
Mayer L.M., 1994a. Surface area control of organic carbon accumulation in continental shelf sediments. Geochimica et Cosmochimica Acta 58, 1271-1284.

Mayer L.M., 1994b. Relationships between mineral surfaces and organic carbon concentrations in soils and sediments. Chemical Geology 114, 347-363.

Mayer L.M., 1999. Extent of coverage of mineral surfaces by organic matter in marine sediments. Geochimica et Cosmochimica Acta 63, 207-215.

Mayer L.M., 2004. The inertness of being organic. Marine Chemistry 92, 135-104.

Mayer L., Schick L., Hardy K., Wagai R., McCarthy J., 2004. Organic matter content of small mesopores in sediments and soils. Geochimica et Cosmochimica Acta 68, 3863-3872.

Means J.C. 1995. Influence of salinity upon sediment-water partitioning of aromatic hydrocarbons. Marine Chemistry 51, 3-16.

Meyers P.A., Quinn J.G., 1973. Factor affecting the association of fatty acids with mineral particles in sea water. Geochimica et Cosmochimica Acta. 37, 1745-1759.

Milliman J.D., 1994. Organic matter content in U.S. Atlantic continental slope sediments: Decoupling the grain-size factor. Deep-Sea Res.II. 1, 797-808.

Mikutta R., Schaumann G.E., Gildemeister D., 2009. Biogeochemistry of mineral-organic associations across a long-term mineralogical soil gradient (0.3-4100 kyr), Hawaiian Islands. Geochimica et Cosmochimica Acta 73, 2034-2060.

Niggeman J., Ferdelman T.G., Ferdelman T.G., Lomstein B.Aa., Kallmeyer J., Schubert C.J., 2007. How depositional conditions control input, composition, and degradation of organic matter in sediments from the Chilean coastal upwelling region. Geochimica et Cosmochimica Acta 71, 1513-1527.

Nir S., Zadaka-Amir D., Kartaginer A., Gonen Y., 2012.Simulation of adsorption and flow of pollutants in a column filter: Application to micelle-montmorillonite mixtures with sand. Applied Clay Science. 67-68, 134-140.

Ortiz M., Berrios F., Campos L., Uribe R., Ramirez A., Hermosillo-Nunez., Gonzalez J., Rodriguez-Zarogoza F., 2015. Mass balanced trophic models and short-term dynamical simulations for benthic ecological systems of Mejillones and Antofagasta bays (SE Pacific): Comparative network structure and assessment of human impacts. Ecological Modelling 309-310, 153-162. 
Pichevin L., Bertrand P., Boussafir M., Disnar J.-R., 2004. Organic matter accumulation and preservational controls in a deep sea modern environment: an example from Nambian slope sediments. Organic Geochemistry 35, 543-559.

Pan C., Feng J., Tian Y., Yu L., Luo X., Sheng G., Fu J., 2005. Interaction of oil components and clay minerals in reservoir sandstones. Organic Geochemistry 36, 633-654.

Ransom B., Bennett R. H., Baerwald R., Shea K. 1997. TEM study of in situ organic matter on continental margins: occurrence and the 'monolayer' hypothesis. Marine Geology $138,1-9$.

Ransom B., Kim D., Kastner M., Wainwright S., 1998. Organic matter preservation on continental slopes: Importance of mineralogy and surface area. Geochimica et Cosmochimica Acta 62, 1329-1345.

Riboulleau A., Derenne S., Largeau C., Baudin F., 2001. Origin of contrasting features and preservation pathways in kerogens from the Kashpir oil shales (Upper Jurassic, Russian Platform). Organic Geochemistry 32, 647-665.

Saidy A.R., Smernik R.J., Bladock., Kaiser K., Sanderman J. 2000 The sorption of organic carbon onto differing clay minerals in the presence and absence of hydrous iron oxide. Geoderma 209-210, 15-21.

Salmon V., Derenne S., Lallier-Vergès E., Largeau C., Beaudoin B. 2000. Protection of organic matter by mineral matrix in a Cenomanian black shale. Organic Geochemistry 31 (5), 463-474.

Sinninghe Damsté J.S., de Leeuw J.W., 1990. Analysis, structure and geochemical significance of organical-bound sulphur in the geosphere: state of the art and future research. Organic Geochemistry 16, 1077-1101.

Site A.D., 2001.Factors Affecting Sorption of Organic Compounds in Natural Sorbent/Water Systems and Sorption Coefficients for Selected Pollutants. A Review. The Journal of Physical and Chemical Reference Data.30, 187.

Satterberg J., Arnarson T.S., Lessard E.J., Keil R.G., 2003 Sorption of organic matter from four phytoplancton species to montmorillonite, chlorite and kaolinite in seawater. Marine Chemistry 81, 11-18.

Sugai S.F. and Henrichs S.M., 1992. Rates of amino acid uptake and mineralization in Resurrection Bay (Alaska) sediments. Marine Ecology, Progess Series 88, 129-141.

Tegelaar E.W., de Leeuw J.W., Derenne S., Largeau C., 1989. A reappraisal of kerogen formation. Geochimica et Cosmochimica Acta 53, 3103-3106. 
Thiebault T., Guégan R., Boussafir M., 2015.Adsorption Mechanisms of Emerging

Micropollutants with a clay Mineral: Case of Tramadol and Doxepine Pharmaceutical Products. Journal of Colloid and Interface Science. 453, 1-8.

Tissot B.P. and Welte D.H., 1984. Petroleum formation and occurrence. 2nd edition. SpringerVerlag, New York, 699 pp.

Turner A., Rawling M.C., 2001.The influence of salting out on the sorption of neutral organic compounds in estuaries. Water Research 35, 4379-4389.

Valdés J., Román D., Alvarez G., Ortlieb L., Guiñez M., 2008. Metals content in surface waters of an upwelling system of the northern Humboldt Current (Mejillones Bay, Chile). Journal of Marine Systems. 71, 18-30.

Valdés J., Sifeddine A., Boussafir M., Ortelieb L., 2014. Redox conditions in a coastal zone of the Humboldt system (Mejillones, $23^{\circ} \mathrm{S}$ ). Influence on the preservation of redoxsensitive metals. Journal of Geochemical Exploration 140, 1-10.

Wakeham S.G., Farrington J.W., Gagosian R.B., 1984. Variability in lipid flux and composition of particulate organic matter in the Peru upwelling region. Organic Geochemistry 6, 204-215.

Wagai R. and Mayer L.M., 2007. Sorptive stabilization of organic matter in soils by hydrous iron oxides. Geochimica et Cosmochimica Acta 71, 25-35.

Wu L.M, Zhou C.H., Keeling J., Tong D.S., Yu W.H., 2012. Towards an understanding of the role of clay minerals in crude oil formation, migration and accumulation. EarthScience Reviews 115, 373-386.

Zhang D., Zhou C.H., Lin C.X., Tong D.S., Yu W.H., 2010. Synthesis of clay minerals. Applied Clay Science 50, 1-11. 


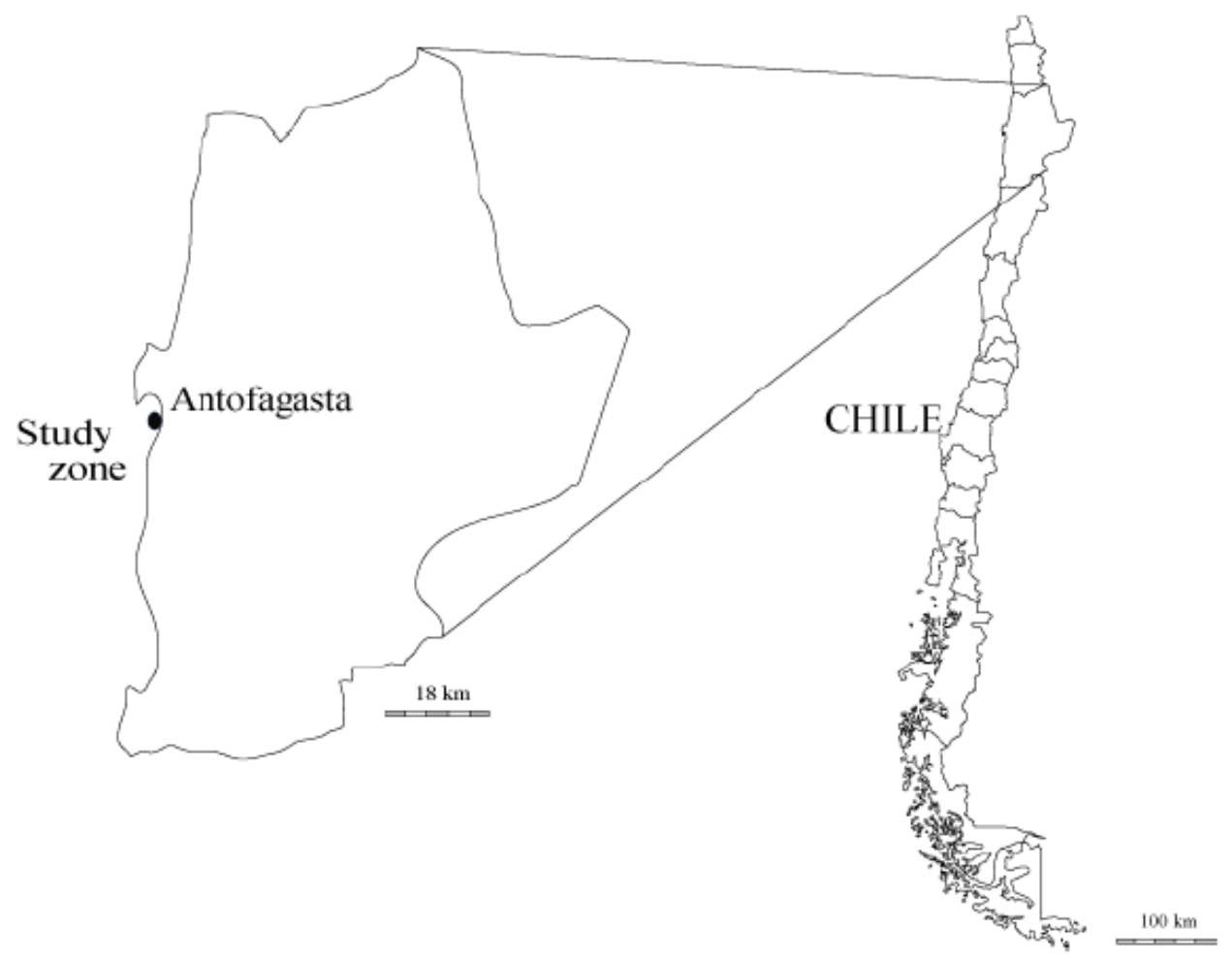

Figure 1 : Study site location (2331'4.6' 'South 70²9'30' 'West). 


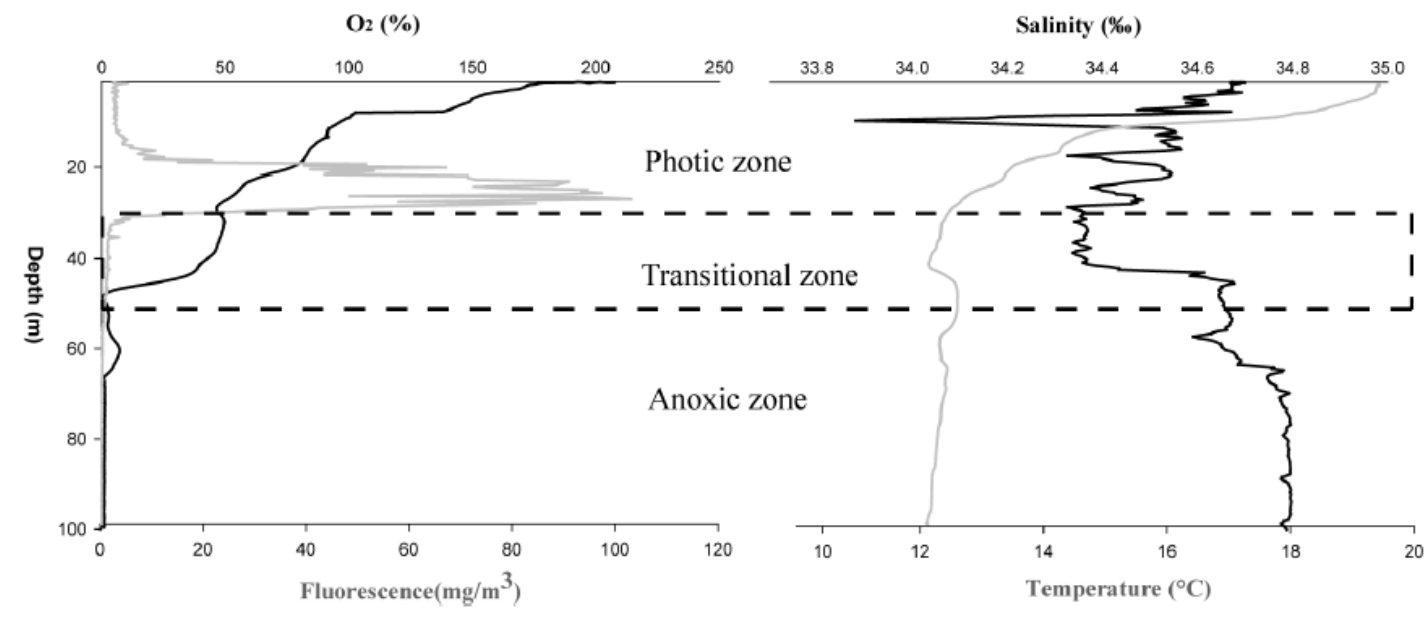

Figure 2: Study site water column physico-chemical characteristics. Clay traps were immersed in the photic, transitional and anoxic zones.
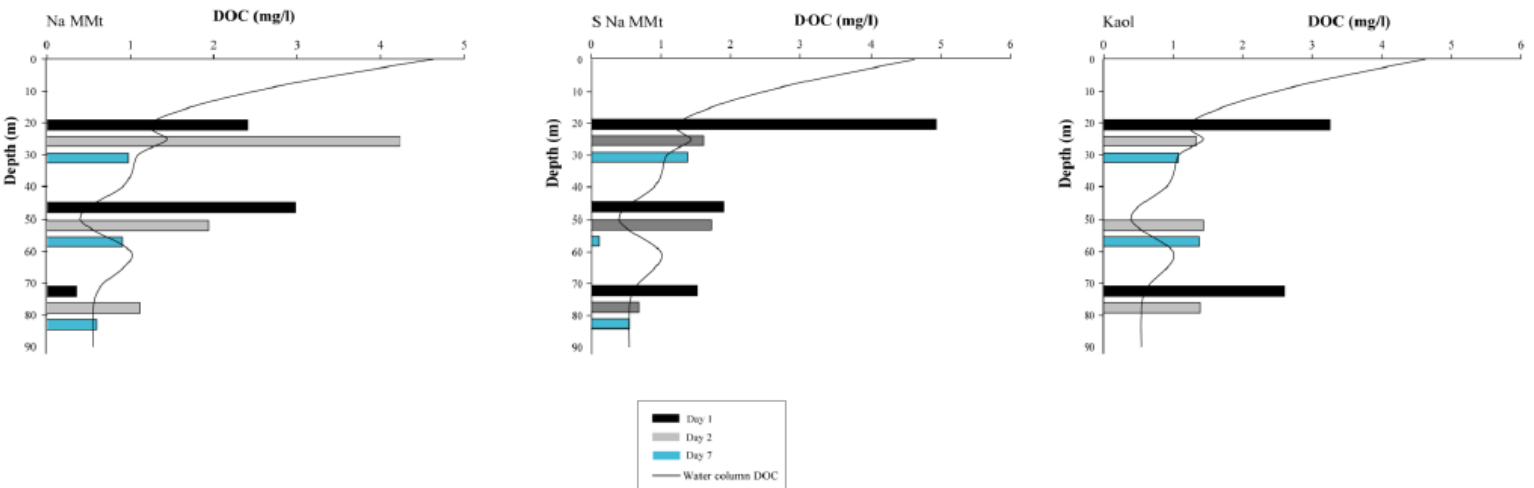

Figure 3: Dissolved Organic Carbon (DOC) concentrations measured in clay traps (horizontal bars) immersed in the photic zone (20m), transitional zone (40m) and anoxic zone $(80 \mathrm{~m})$. The continuous line represents DOC concentrations measured in seawater. 

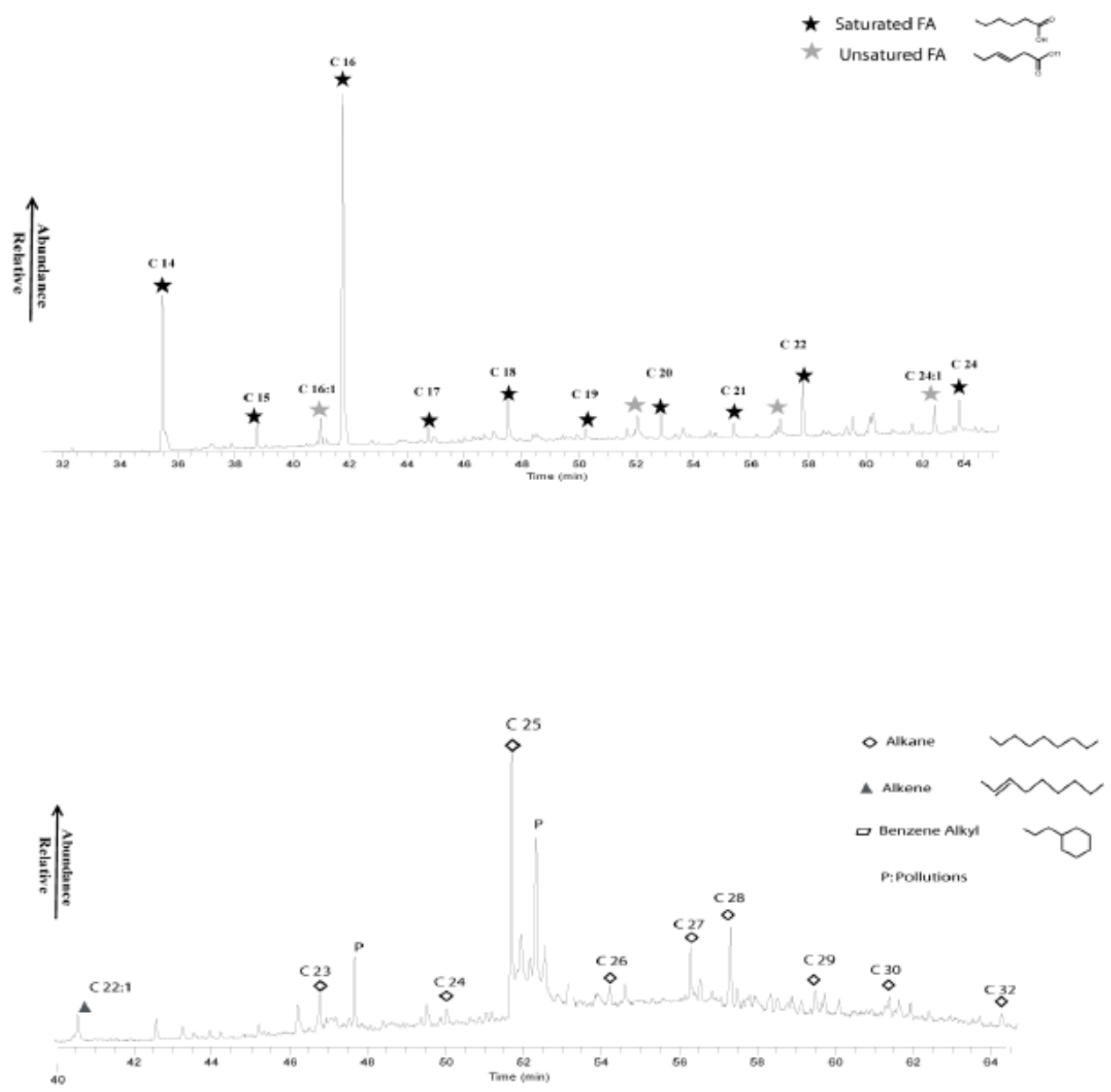

Figure 4: Total Ionic Current (TIC) obtained for water sample extracts in the photic zone (the same results were observed in the transitional and anoxic zones). The upper TIC represents acidic fraction results, the lower one represents neutral fraction results. 

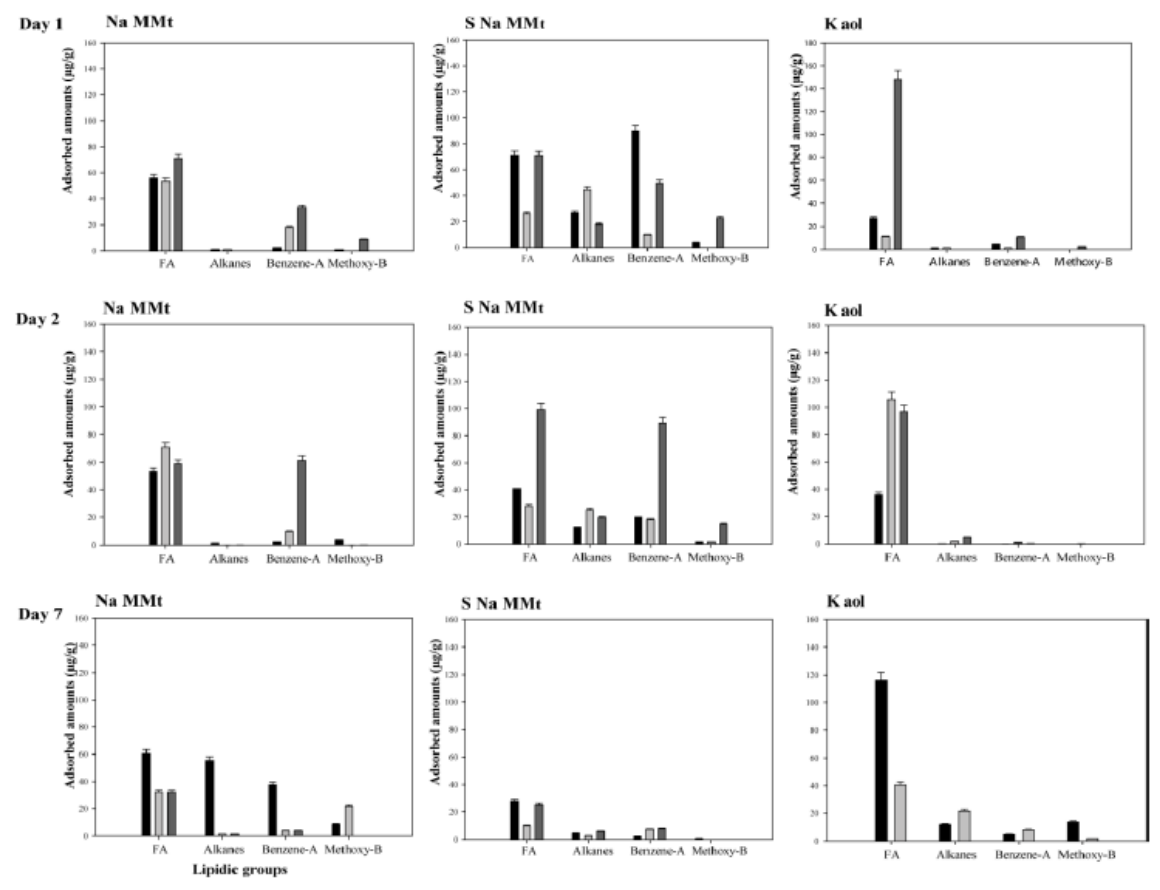

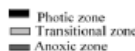

Figure 5: Main lipidic groups adsorbed on immersed clay samples. 

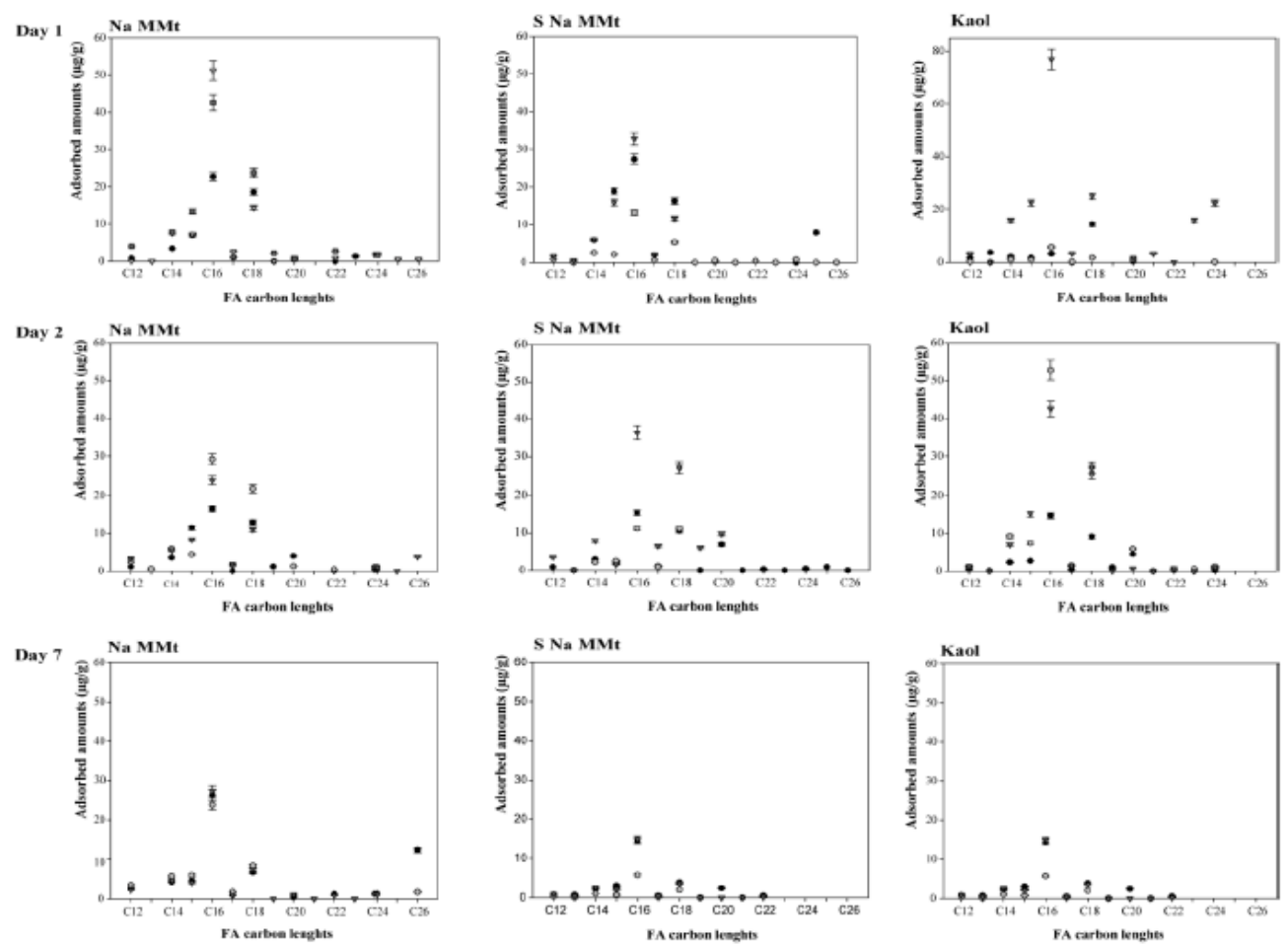

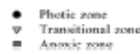

Figure 6: Fatty acid amounts on immersed clay samples.
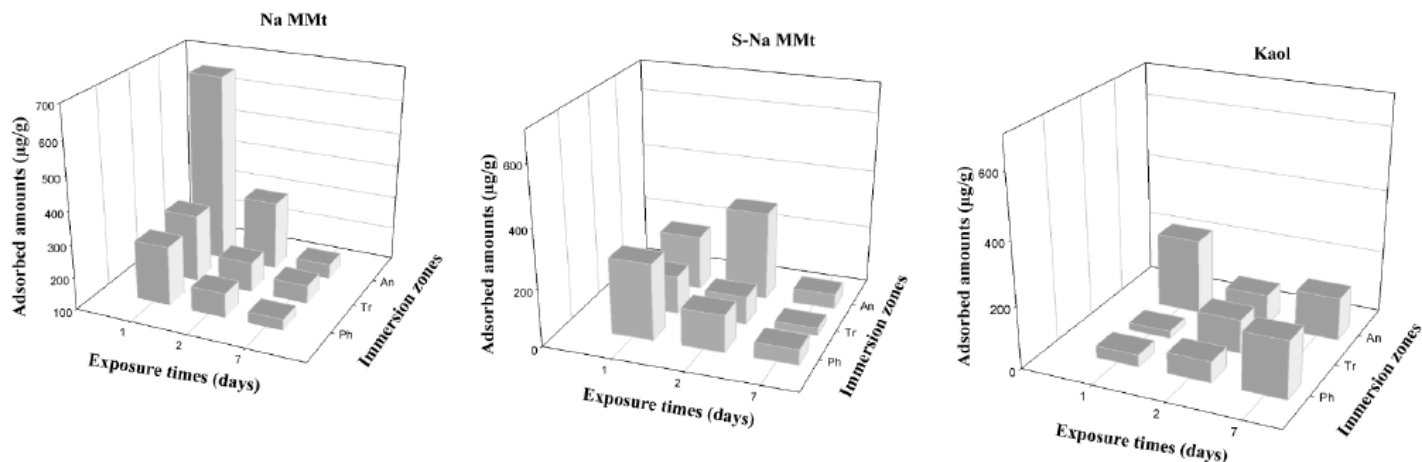

Figure 7: Total lipid amounts adsorbed on immersed clay samples. (Ph: Photic zone; Tr: Transition zone; An: Anoxic zone). 


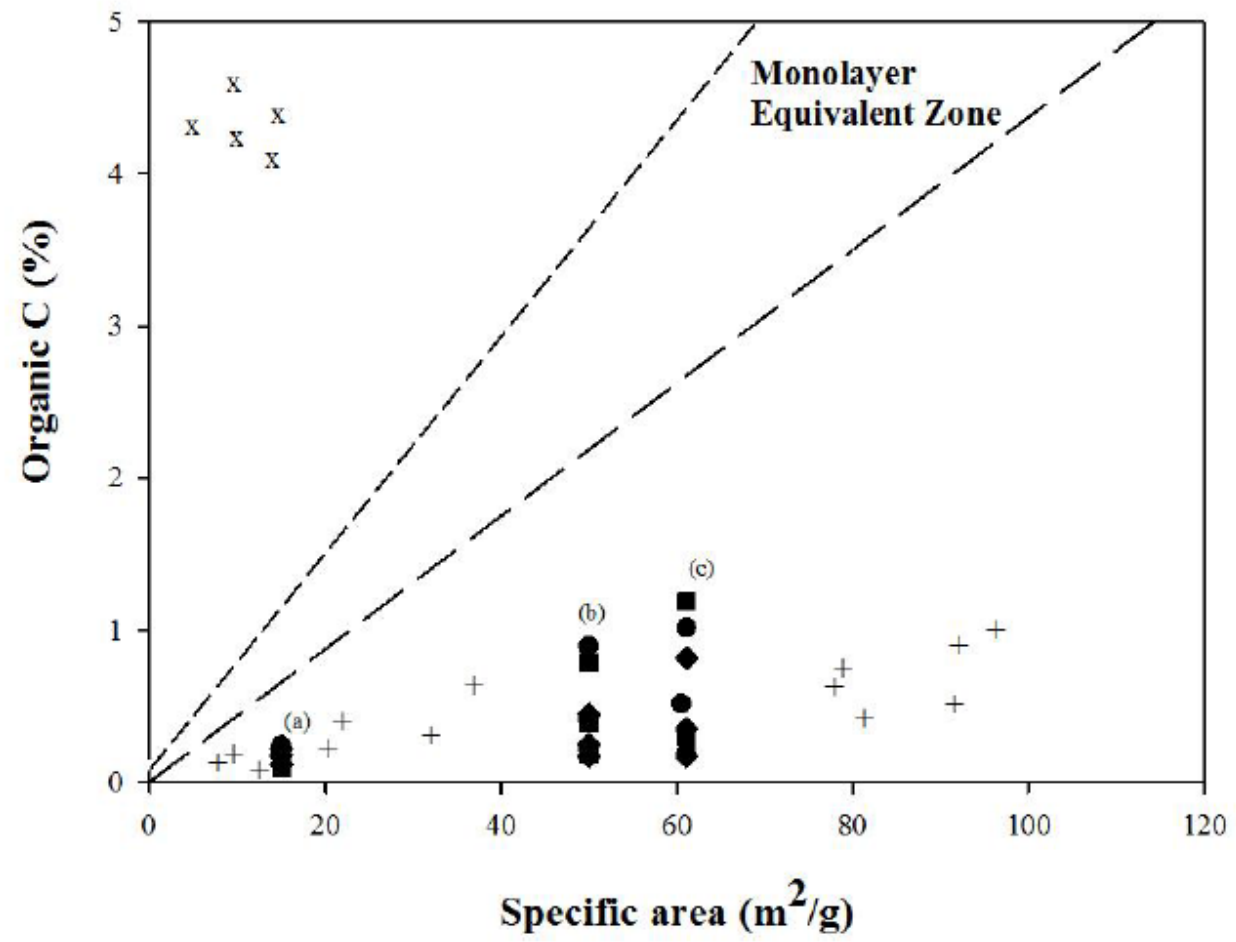

Figure 8: External specific areas of clays versus sorbed organic amounts on kaolinite (a) Natural montmorillonite (b) and synthetic montmorillonite (c) samples. Circles, squares and diamonds represent respectively the photic, transitional and anoxic zones. Black sea(x) and Equatorial Pacific (+) sediments are also represented (Data from Hedges and Keil 1995). 

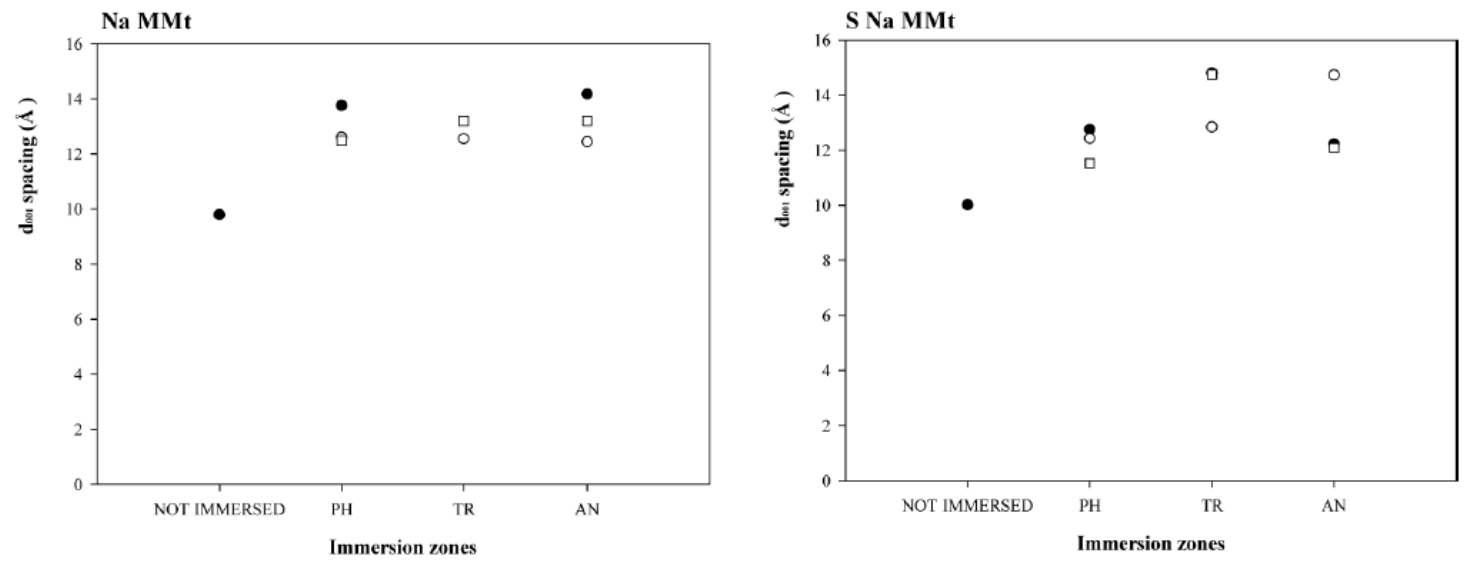

- Day 7

\begin{tabular}{ll}
0 & Day 2 \\
\hline & Day 1
\end{tabular}

Figure 9: Immersed montmorillonites $d_{001}$ spacing compared with non-immersed samples. (PH: photic zone; TR: transitional zone; AN: Anoxic zone)

\begin{tabular}{|l|l|l|}
\hline & $\begin{array}{l}\text { CEC (meq/100 } \mathrm{g} \text { of } \\
\text { calcined clay) }\end{array}$ & Specific area $\left(\mathrm{m}^{2} / \mathrm{g}\right)$ \\
\hline S Na MMt & 83 & 763.8 \\
\hline Na MMt & 85 & 736.8 \\
\hline Kaol & 5 & 15 \\
\hline
\end{tabular}

Table 1: Clays' physical characteristics (CEC: Cationic Exchange Capacity). 


\begin{tabular}{|l|c|}
\hline & $\begin{array}{c}\text { Blank traps } \\
\text { DOC }(\mathbf{m g} / \mathrm{g})\end{array}$ \\
\hline Photic zone & $2.25 \pm 0.11$ \\
\hline Transition zone & $1.40 \pm 0.07$ \\
\hline Anoxic zone & $0.37 \pm 0.02$ \\
\hline
\end{tabular}

Table 2: Dissolved Organic Carbon concentrations measured in traps without clay samples (with mean error margins obtained for triplicated measures). The empty cylinders were immersed in the photic zone $(20 \mathrm{~m})$ transition zone $(40 \mathrm{~m})$ and anoxic zone during 2 days. 


\begin{tabular}{|c|c|c|c|c|c|c|c|c|c|c|}
\hline & \multicolumn{3}{|c|}{ Day 1} & \multicolumn{3}{|c|}{ Day 2} & \multicolumn{3}{|c|}{ Day 7} \\
\hline & & PH & TR & $\mathbf{A N}$ & $\mathbf{P H}$ & TR & $\mathbf{A N}$ & PH & TR & $\mathbf{A N}$ \\
\hline \multirow{4}{*}{$\begin{array}{c}\text { Na } \\
\text { MMt }\end{array}$} & FA & 46.15 & 136.15 & 131 & 43.95 & 181.37 & 109.15 & 49.95 & 81.91 & 59.16 \\
\hline & Alkanes & 0.86 & 2.59 & - & 0.99 & 0.13 & 0.38 & 45.79 & 3.34 & 2.40 \\
\hline & $\begin{array}{c}\text { Benzene- } \\
\text { A }\end{array}$ & 2.01 & 46.29 & 61.92 & 1.56 & 24.96 & 113.56 & 3113 & 9.93 & 7.16 \\
\hline & $\begin{array}{c}\text { Methoxy- } \\
\text { B }\end{array}$ & 0.76 & - & 15.96 & 2.81 & 0.05 & 0.35 & 7.20 & 55.60 & - \\
\hline & & & & & & & $\forall$ & & & \\
\hline \multirow{4}{*}{$\begin{array}{l}\text { S Na } \\
\text { MMt }\end{array}$} & FA & 58.63 & 66.74 & 130.95 & 33.66 & 71.76 & 183.37 & 23.15 & 10.05 & 46.57 \\
\hline & Alkanes & 22.06 & 114.44 & 33.15 & 10.43 & 64.12 & 35.67 & 3.78 & 2.60 & 11 \\
\hline & $\begin{array}{c}\text { Benzene- } \\
\text { A }\end{array}$ & 74.13 & 24.68 & 91.71 & 16.35 & 45.26 & 165.42 & 1.87 & 7.30 & 14.65 \\
\hline & $\begin{array}{c}\text { Methoxy- } \\
\text { B } \\
\end{array}$ & 2.96 & - & 41.68 & 1.01 & 3.28 & 27.57 & 0.63 & - & - \\
\hline & & & & & & & & & & \\
\hline \multirow{4}{*}{ Kaol } & FA & 22.19 & 10.87 & 274.63 & 29.69 & 271.37 & 179.07 & 96.01 & - & 75.20 \\
\hline & Alkanes & 1.10 & 1.42 & - & 0.18 & 3.90 & 8.40 & 9.93 & - & 39.90 \\
\hline & $\begin{array}{c}\text { Benzene- } \\
\text { A }\end{array}$ & 3.31 & 1.44 & 19.37 & 0.10 & 1.96 & 0.54 & 3.91 & - & 14.94 \\
\hline & $\begin{array}{c}\text { Methoxy- } \\
\text { B }\end{array}$ & - & & 4.42 & - & 0.54 & - & 11.42 & - & 3.31 \\
\hline
\end{tabular}

Table 3: Sorbed lipids groups amounts normalized by adjacent DOC concentrations. Data are dimensionless. (PH: photic zone; TR: transitional zone; AN anoxic zone). 


\begin{tabular}{|l|l|l|l|l|l|l|l|l|l|l|}
\hline & \multicolumn{3}{|c|}{ Day 1 } & \multicolumn{3}{c|}{ Day 2 } & \multicolumn{3}{c|}{ Day 7 } \\
\cline { 2 - 10 } & PH & TR & AN & PH & TR & AN & PH & TR & AN \\
\hline Na MMt & 82.6 & 780.90 & 1240 & 143.67 & 488.86 & 572.41 & 110.48 & 398.96 & 268.58 \\
\hline S Na MMt & 216.90 & 333.83 & 348 & 106.43 & 246.32 & 563.82 & 43.97 & 67.12 & 94.68 \\
\hline Kaol & 31.54 & 59.79 & 443.45 & 55.84 & 277.77 & 188.25 & 152.01 & & \\
\hline
\end{tabular}

Table 4: Sorbed amounts normalized with adjacent DOC concentrations (values in appendix 1). Data were obtained through the normalization operation of sorbed lipids amounts $(\mu \mathrm{g} / \mathrm{g})$ by water column data initially expressed in $\mathrm{mg} / \mathrm{l}$ (figure 3 ) and converted in $\mu \mathrm{g} / \mathrm{g}$. The resulting values are dimensionless. (PH: photic zone; TR: transitional zone; AN anoxic zone). 


\section{Highlights}

- Organo-clay interactions have been performed in a productive seawater column (Antofagasta Bay, Chile).

- Excess of DOC concentrations have been noted in the clays traps compared to the seawater values.

- Among the experimented clays, $\mathrm{Na}$ exchanged montmorillonite exhibited the best sorption rates.

- The anoxic zone of the water column was the most propitious zone for the sorption process. 